\title{
Calculating the Storage Capacities of Granaries: a Tentative Model
}

\author{
Stéphane Martin
}

The previous two chapters present differing views on the feasibility and the utility of calculating storage capacities. There is no doubt that exact calculations will always elude us, for lack of proper sources. In his contribution, Lars Blöck insists rightly on the modelling aspect of his calculations. Notwithstanding the justified scepticism of Javier Salido Domínguez, it remains true that even the maximum capacities estimated by Lars Blöck lead to a serious reappraisal of previously published estimates. However, Blöck himself stresses that his model is designed for the area corresponding to modern south-west Germany and that it should not be applied as it stands to other regions. The aim of this chapter is to present and study in greater detail the various parameters necessary for calculating storage capacities, in order to set out what could be considered an average situation, valid for the whole of the research area, and possibly beyond.

In the north-western provinces, airtight storage in underground silos is not attested during the Roman period: it disappeared at the end of the Iron Age (La Tène D) until the Early Middle Ages (see Chapter 4 for the Iron Age, and various contributions in Vigil-Escalera, Bianchi, and Quirós Castillo 2013 for the Middle Ages). Calculating the storage capacities of an underground silo is fairly easy, since grain will be preserved only if the silo is completely filled before being sealed. Underground silos thus offer one of the rare cases when the total volume of a structure equals it operating volume. However, it should be noted that for Frédéric Gransar, Iron Age silos were used to store grain in spikes or spikelets, whereas for François Sigaut, silos are mainly used for grain that was already threshed and winnowed (Sigaut 1988; Gransar 2003). Sigaut does mention underground storage of spikelets, but as an uncommon phenomenon. Sigaut used mainly historical and ethnographical documentation, whereas Gransar used archaeological evidence: this may well be the main reason for their differing interpretations. This matter is nonetheless worth exploring further, since chaff can represent 10 to $50 \%$ of the total weight of hulled grain (Ouzoulias 2006, 174. For emmer and spelt, see also Saunders 1904 who gives a lower proportion of chaff than Ouzoulias). 
As evidenced by clear archaeological data, the shape and size of granaries from the Roman period differed from their Iron Age predecessors (see Part II of this volume). In most regions, wooden granaries on posts were gradually replaced, from the first century CE onwards, by larger, stone-built structures. However, the underlying technical principles of storage remained unaltered: grain was still preserved through control of the atmosphere by ventilation (to use the categories devised by Sigaut 1988, 17). The following discussion therefore concerns all granaries, regardless of their architectural type and their chronology. There is likewise no technical difference between a small rural granary and a big urban or military structure. For this reason, it is legitimate, in my view, to use data from non-rural contexts to understand storage in the countryside and vice versa. However, due consideration must be given to at least two factors. First, the function of the storage structure under study in the chain between harvest and supply. This chapter will focus on storage in a rural context, in most cases on production sites. What is at stake is therefore likely to be mid- to long-term storage, either for on-site use and consumption, or for sale on the market at a later date, with good conservation as the main goal. Second, our reconstructions must naturally take into account all available archaeological data; primary evidence, however meagre, should guide our use of historical and ethnographical comparisons, and should take precedence over evocative but sometimes ill-founded parallels (see Halstead 1987, with examples from the Mediterranean).

In trying to assess the storage capacities of granaries, scholars have taken two approaches. The older attempts took their cue from the buildings' architecture, generally taking storage in bulk as a given. Thus Francis Haverfield and Robin Collingwood for wooden, and Anne Gentry for stone military granaries in Britain (Haverfield and Collingwood 1920; Gentry 1976). The first two authors thought that grain was stored in bulk, stacked in bins against the walls to an average height of 6 feet (ca. $1.80 \mathrm{~m}$ ) on both sides of a central corridor. Gentry calculated that the walls of the Corbridge granary could stand the pressure of a grain heap of ca. $3 \mathrm{~m}$ (but this was not her favoured solution, as she thought grain was stored in sacks). ${ }^{1}$ More recently, Emanuele Papi and Francesco Martorella (2007) used the same method to reconstruct heaps as high as $4.90 \mathrm{~m}$ in a granary in Thamusida (in modern Morocco)! 2 Without using such calculations, Gustav Hermansen (1982, 226-37) combined evidence from present-day Canada, where a storage height of 8 feet (ca. $2.45 \mathrm{~m}$ ) is common, with the

1 With Richmond and McIntyre 1938-1939, these works have been the basis of all subsequent calculations for Roman military granaries, listed in Salido Domínguez 2011, 53.

2 Even if this granary is considered as a transit warehouse, i.e. for short-term storage before shipment, as is the case of Federico De Romanis (2007), such a height is surely excessive. 
height of the storerooms in Ostia and Portus near Rome, to suggest 3 and $4 \mathrm{~m}$ heights for grain heaps in horrea from each site (he does acknowledge that these are maximum values, and that it is rather impractical to store grain in heaps higher than $2 \mathrm{~m}$ ).

This approach, which does not seem to have been applied to rural buildings, either does not give due consideration to the conditions necessary for grain preservation, ${ }^{3}$ or, in the case of Hermansen, rests rather uncritically on recent parallels. Funnily enough, the thickness of granary walls does not seem to be interpreted in terms of thermal insulation, although this was well known to an eighteenth-century writer such as the abbot Tessier: "Les murs doivent être de bonne épaisseur, pour garantir les blés de l'humidité \& de la chaleur" (Tessier 1793, 46o; Plin. Nat. 18.300 is rather ambiguous but might be pointing to something similar).

The second method starts from the nature of the stored produce rather than from the building. This appears wiser since, as Sigaut wrote (e.g. 1988, 18-19), storage structures are generally built according to the form of the produce. It is clear from various kinds of evidence that a single granary could host a variety of products, either different types of grain as for example in Amiens "ZAC Cathédrale" and Tiel "Passewaaij", granary 47, or different types of produce, e.g. grain and legumes in Alle (Matterne, Yvinec, and Gemehl 1998, here cat. 250; Kooistra and Heeren 2007, here cat. 312; Demarez et al. 2010, here cat. 125 and 221). Furthermore, not everything might be for human consumption, although it can be difficult to distinguish between food and fodder (Jones 1996). However, much of the archaeological evidence does relate to the storage of grain and in the following pages, the focus will be on wheat and barley, the main crops for the period and region under study.

The calculation of storage capacities needs to take four main parameters into account. The first one is obviously which crop is stored, since density varies from species to species. The second parameter is closely linked to the first: in what form is grain stored, i.e. how advanced is the processing of grain when it is brought into storage?

Sigaut $(1988,6)$ distinguished among several forms of grain storage. Sheaves are notoriously hard to find in the archaeological record, all the more so because they can be stored in stacks and leave no tangible traces. Some buildings have been identified as barns but only on typological grounds (Ferdière 1985). We do have hard evidence for storage of grain in bulk and grain in spikes or spikelets. The difference between naked or dehusked grain on the one hand,

3 Although he also recreates heaps resting against the walls of the Grandi Horrea in Ostia, Nicolas Monteix, in Boetto et al. 2016, 213-20, does take these parameters into account, which leads him to propose a much more reasonable $1.60 \mathrm{~m}$ as a likely height. 
and hulled grain on the other, is key to understanding the nature of storage. Lars Blöck notes that finds of hulled grain appear more frequent in rural contexts, while dehusked grain is more common in urban and military settings (Blöck 2011-2012, 93-4). This is logical since grain stored hulled or mixed with chaff can be preserved for a longer period, as was already known to ancient authors (Plin. Nat. 18.306; see also Var. R. 1.72). Various estimates of grain density have been put forward; further research is needed but for the region under study, the data compiled by Pierre Ouzoulias will be used here, as they appear both consistent with ancient sources and with proposals by other authors (Ouzoulias 2006, 173-76. For emmer and spelt, Saunders 1904 and Stallknecht, Gilbertson, and Ranney 1996, both using North American data, give slightly lower values. But figures given in Kooistra 1996, 98 and 318, appear decidedly too low: see Chapter 6, this volume).

As a general rule, we should assume, for our calculations, storage in spikelets or with chaff, rather than threshed and winnowed grain. Indeed, in the small urban granary of Amiens "ZAC Cathédrale", the main crop, spelt wheat, was stored hulled (Matterne, Yvinec, and Gemehl 1998). If this building was the storage facility of a merchant, as hypothesized by the authors, this means he bought the grain unprocessed from the producer. The merchant would have had the grain threshed and winnowed later, before sale: it is clear from the Edict of Maximum Prices that selling fully processed barley was much more profitable (10o denarii per modius instead of 30 for husked grain: Edict. Diocl. 1.7) ${ }^{4}$ However we should not completely rule out the possibility that grain was processed and sold directly by the producer (or the owner of the estate). The rare discovery of a second-century CE shipwreck with its cargo in Woerden $(\mathrm{NL})$ confirms that grain could be shipped in bulk, threshed and winnowed (Pals and Hakbijl 1992; see Haalebos 1996 for the archaeological context). The grain appears to have been stored for some time, already threshed and winnowed, before shipment: there is no way to decide whether this storage took place on the production site or elsewhere.

The third parameter to consider is the usable surface area of the granary. The need for free space is regularly mentioned in agronomic literature, at least since Olivier de Serres $(1600,135)$, but although Haverfield and Collingwood took it into account in 1920, it does not appear in all estimates of storage capacity. The necessary amount of free space is conditioned by the form of storage.

There are three ways of storing grain in granaries: in bulk, in bins or in sacks (to my knowledge, storage in large jars, as known in the Mediterranean, is not attested in north-western Europe). Storage in bins is now rejected by all

4 Reference kindly supplied by Pierre Ouzoulias. 
scholars for one good reason: there is no archaeological evidence for it, even in the best preserved granaries (Rickman 1971, 85; Gentry 1976, 18).

Storage in bags is favoured by some, most notably Geoffrey Rickman and Anne Gentry, followed by Anne Johnson (1983) and more recently by Tobias Schubert $(2016,336-37)$ in his dissertation on rural granaries from the Lower Rhine. ${ }^{5}$ In all cases, the authors consider the grain naked or threshed and winnowed. The first two had a very rational approach, underlining the practicalities of storage in sacks for handling (Rickman 1971, 85-86; Gentry 1976, 18-22). But one can agree with Catherine Virlouvet and Nicolas Monteix when, discussing Rickman, they write that although his ideas look good on paper, he underplays the constant care needed by grain unless it is very dry (Virlouvet 2015, 680; Monteix in Boetto et al. 2016, 213-14). Furthermore, the presence of saccarii near horrea does not mean that goods were necessarily carried in bags, since the term apparently designated all kinds of porters (Virlouvet 2015, 67677). Schubert $(2016,336)$ adds one piece of archaeological evidence in favour of storage in sacks. In 1818, a fourth-century CE burgus was excavated in Engers (near Koblenz, DE). The evidence points to a violent destruction by fire already in ancient times, which led to the charring of large quantities of grain, mixed with melted lead. The presence of this lead, as well, according to Schubert, as the mixture of various kinds of grain, is for him evidence that grain was stored in bags. It is worth citing here the original report as published in 1826:

Ausser den römischen Gussmauern und sonstigen Baumaterialien gehören zu den umbezweifelt achten, hier vorgefundenen Anticaglien, die Scherben von terra cotta, Gefässstücke aus grobem Thon; so wie die sehr grosse Masse verbrannten Getraides, welches in Schichten von 3 bis 9 Zoll Dicke [ca. 8 to $24 \mathrm{~cm}$ ], an einigen Stellen sogar mehrere Fuss hoch lag [in this case, 1 foot = ca. $29 \mathrm{~cm}$ ]; es war Roggen [rye], Gerste [barley], meistens aber Weizen [wheat], wahrscheinlich also ein Getraide-Magazin gewesen. Die Menge grosser Stücke tropfsteinartig geschmolzenen Bleies, die sich in dem Getraide vorfanden, könnten zu der Vermuthung fuhren, der Thurm sei mit Bleiplatten gedeckt gewesen (Dorow 1826, 24).

First of all, nowhere is it written that the various kinds of grain were mixed. Second, although it is written that lead was indeed found in the grain, it is not clear why this should indicate storage in bags, all the more since Schubert accepts Dorow's interpretation that it came from the roof. Third, 8 to $24 \mathrm{~cm}$ layers are consistent with storage in bulk; heaps several feet high less so, but the original report seems to indicate that this was not the general situation (see below for a discussion of the height of the heap). Based on comparison with similar

5 One can also cite Donald Strickland (1987) whose approach is less satisfactory than the others: storage in sacks is taken for granted because it is modern practice, and it is not specified whether the grain is hulled or not. 
buildings, there was probably at least one upper-floor: could the grain have fallen during or after the fire (see the better preserved burgus in Zullestein: Baatz in Reddé et al. 2006, 227-28, s.v. Biblis)? Most importantly, the type of site must be taken into consideration: Engers is a late-antique fortified post interpreted as a harbour or a landing station, probably built during Valentinian's reorganization of the Rhine frontier. Can the storage method adopted in this context be applied to earlier civilian contexts?

This does not mean that storage in bags did not exist; during the excavation of Amiens "ZAC Cathédrale", some textile fibres were recovered among the grain, possibly indicating sacks (Matterne, Yvinec, and Gemehl 1998, 106). But it should be remembered that we are dealing here with hulled spelt, and not naked or dehusked grain, stored in a probable merchant warehouse, and not on a production site. As a general rule, sacks are only adapted to short-term storage (Geraci and Marin 2016, 88).

All in all, storage in bulk, whether the grain was fully processed or still in spikelets, is the most likely solution. For what this testimony is worth, it should be noted that storage of hulled grain on the floor is described in the peasantsetting of the Moretum, a short poem formerly attributed to Vergil (Mor. 16). ${ }^{6}$ It is thus supported by archaeological and textual evidence, as well as historical and ethnographical parallels.

In military granaries, or more generally large rectangular granaries, scholars normally assume a central corridor at least as wide as the entrance door, with grain stacked in heaps against the walls. Haverfield and Collingwood, Gentry, Papi and Martorella, and Monteix, concord on this point. Yet from the eighteenth century onwards, agronomists insist on the need to keep some free space between the walls and the heaps, varying from ca. 30 to $120 \mathrm{~cm}$ ( 1 to 4 feet) (Table 3.1). In addition to providing room to move around, this was to avoid both dust and pests falling from the walls, and grain falling in the gaps between the wall and the floor (particularly if it was made of boards).

To this should be added the space necessary for accessing the granary and walking around the heaps, whether a single central corridor or smaller passageways. Finally, extra space is needed if grain is stored threshed and winnowed, because it needs frequent shovelling. The operation consists in moving the grain from one place to another by tossing it in the air with a shovel (hence the name). It should be done very frequently in the first six months after the harvest, with decreasing frequency until the end of the first or second year (authors vary). The problem with shovelling in Antiquity is that ancient authors

6 The evidence of the archive of the Sulpicii, a family of tradesmen from Puteoli, also seems to point to storage in bulk: TPSulp. 45 and 46 , commented on with differing conclusions by Virlouvet 2000 and Jakab 2014. 
TABLE 3.1 Free space between heaps of grain and walls according to various authors

Publication

Duhamel 1768

Duhamel 1768

Krünitz 1788

Diffloth 1907

Haverfield and Collingwood 1920

Richmond and McIntyre 1938-1938

Demarez et al. 2010

\section{Free space}

ca. $60 \mathrm{~cm}$ between wall and grain

In the Grenier d'Abondance in Lyon, ca. $120 \mathrm{~cm}$ between wall and grain

ca. $60 \mathrm{~cm}$ between wall and grain 40 to $50 \mathrm{~cm}$ between wall and grain, and a central passage at least $100 \mathrm{~cm}$ wide Central corridor of ca. $90 \mathrm{~cm}$ (theoretical)

Central corridor of ca. $300 \mathrm{~cm}$ (theoretical) $100 \mathrm{~cm}$ around heap of grain (theoretical)

apparently do not mention it at all; textual evidence of this practice is first attested in the sixteenth century (Beutler 1981, 37-39). This led Sigaut (1988, 8 ) to think that it had not become common practice until the eighteenth century. However, it is hard to conceive storage of threshed and winnowed grain in bulk (archaeologically attested in Roman times) without shovelling: this would have led to an incredibly high rate of wastage hardly compatible with the existence of surpluses needed to feed city-dwellers and soldiers (on the need for shovelling, similar view in Matterne 2001, 150; on wastage, see below). Shovelling is apparently not needed when grain is stored hulled or mixed with chaff (Beutler 1981, 36; in the second half of the eighteenth century, this storage method was apparently disappearing; see also Sigaut 1981, 165, and 1988, 13-14).

Given these various factors and the absence of ancient documentation on the matter, not to mention the fact that the situation may have varied with time and space, it is very hard to give an estimate of free space. Recently, Jean-Daniel Demarez, studying the granaries from Alle, put forward the hypothesis that storage in heaps would have left $70 \%$ of the granary unused (and "only" 40\% if produce was stored in bins: Demarez et al. 2010, 393-94). However, this is nothing more than an educated guess and it seems safer to turn to historically attested examples. I found two, both from the eighteenth century and both for threshed and winnowed grain in bulk. Very recently (2016), Enrico Da Gai and Giulia Vertecchi published a 1788 document regarding the calculation of the storage capacities of the public granaries in Terra Nova in Venice (buildings now destroyed, but well documented). They arrive at a maximum usable surface area of ca. $85 \%$ of the total area. This is very close to the conclusions reached by Duhamel du Monceau in 1768 about the maximum usable 
surface area of the Grenier d'Abondance from Lyon. He calculated a maximum value of $81 \%$ of the total area, but noted himself that the available free space would be barely sufficient (Duhamel du Monceau 1753, 235-36, 1768, 249-51). Earlier in his book, making a theoretical calculation, he had come to the conclusion that $68.5 \%$ of the total area could be used for storing grain in heaps (Duhamel du Monceau 1753, 14-16, 1768, 13-16). Interestingly, the space needed for shovelling only accounts for less than $3 \%$ of the total area of the granary; but this is in stark contrast with the recommendations by Paul Diffloth in 1907, who wrote that to each heap of grain should correspond the same surface of free space, in order to shovel the grain from one spot to another (Diffloth 1907, $360) .{ }^{7}$ All in all, it seems advisable to consider that when grain is stored in bulk, be it threshed and winnowed, with chaff or in spikelets, at least $1 / 3$ of the granary needs to be kept free. Further research is needed to determine whether the examples quoted here are representative of ancient practices.

The fourth parameter is closely linked to the previous one and concerns the height of the grain heap. Figures found in the literature vary from 20 to $490 \mathrm{~cm}$. In Table 3.2, I have compiled as much data on the subject as was available to me (but with no claim to exhaustivity). I have classified it according to the nature of the reasoning: unknown, based on the architecture of the storage building, based on agronomy and/or historical examples (it is often hard to distinguish between the two in older literature), based on archaeological evidence.

Table 3.2 makes it very clearly that a mean height of 20 to $40 \mathrm{~cm}$ is consistent with archaeological data, agronomic literature and historical cases from the seventeenth to the early twentieth centuries. This margin, given by almost every author for fresh grain (Reneaume is an exception), can be applied with confidence to the ancient countryside: since harvests were annual, grain stored on rural sites was mostly fresh. The discovery of Amiens "ZAC Cathédrale" shows that these values apply both to hulled and naked or dehusked grain. Since archaeological finds consist mainly of charred grain, it is important to note that charring has a significant impact on the weight but not on the volume of the grain (Ferrio et al. 2004, in particular 1636, tab. 1 and 1638, tab. 2). It should be stressed that layers might not always be fully preserved, although it appears to be the case in Amiens.

The maximum height of the heap for dry grain is much more variable. Sigaut gives $100 \mathrm{~cm}$ as a maximum for grain stored in bulk and shovelled; in the late eighteenth century, similar values are given by Krünitz and Tessier. But in

7 Various scholars, including Ferdière in this volume (Chapter 5), cite a later edition (1917) of Diffloth's work. I have not been able to consult it, but the contents appear to be the same. 
the early twentieth century, Diffloth and the Larousse agricole give lower figures, as does the Venetian archival document from 1788 cited above. The finds from Ribchester (up to $60 \mathrm{~cm}$ ) and Engers (several feet at some points), both military, may thus have consisted of dry grain.

Of course, the grain heap cannot be entirely flat. Grain being a semi-fluid, the heap is conical in shape. It is stable when the angle is within the range of 25 to $30^{\circ}$ (De Lucia and Assenato 1992 [fr] = 1994 [en], appendix 2; Brinkkemper 1993, 150; see also Monteix in Boetto et al. 2016, 215 with note 113. In this volume, Ferdière opts for an angle of $45^{\circ}$ which may thus be too steep). In theory, then, the wider the heap, the higher it may be. Otto Brinkkemper (1993, 149-50), for instance, trying to work out the storage capacity of two granaries with a usable surface area of ca. $16 \mathrm{~m}^{2}$, reconstructs a single heap reaching 115 $\mathrm{cm}$, with a $30^{\circ}$ slope, equivalent to an even layer of grain $30 \mathrm{~cm}$ thick. Although Brinkkemper deals with hulled crops, this raises questions about the preservation of the grain in the centre of the heap. Several small heaps seem more likely: such is the case in the photographs from a modern granary in Heilbronn republished by Schubert $(2016,337)$. Furthermore, when different crops are stored in the same room, a case often encountered in excavations, they are always stored separately. In our calculation, assuming an even layer with a mean thickness of $30 \mathrm{~cm}$ should therefore be a good approximation of real conditions in ancient times.

In the light of the evidence presented in Table 3.2, figures above $100 \mathrm{~cm}$ for grain storage in bulk appear overestimated. Grain cannot be stored for any length of time in such conditions and too high a heap renders shovelling very impractical, if not impossible. If one accepts such values, one must also assume very high wastage. Estimating wastage during storage and calculating storage capacities are two different issues, but both must be tackled if we are to understand how storage facilities were managed and what proportion of agricultural surplus was actually available.

André Tchernia noted that a $20-25 \%$ wastage rate was generally assumed for granaries of the Roman period, but that the figure was not supported by scientific studies (Tchernia 2011, 245-46 $=2016$, 194; see Papi and Martorella 2007 , 90 for a $25 \%$ wastage rate given without justification). Véronique Matterne arrives at a similar figure for Amiens "ZAC Cathédrale", with $20 \%$ of the stock unfit for human consumption and 90\% germinated (Matterne, Yvinec, and Gemehl 1998, 109-10. See also Smith and Kenward 2011 on pests, whose effects were overestimated by Buckland 1978). But we are dealing here with consumer, not production sites. Sigaut $(1981,165)$ wrote that on the whole peasants tend to take better care of their stocks and to reduce wastage; indeed, research on developing countries (mainly from the southern hemisphere) reports 
TABLE 3.2 Height of grain heaps in the historical, agronomic and archaeological literature

\begin{tabular}{lll} 
Type source & Publication & Height cm \\
\hline Unknown & Haverfield and Collingwood 1920 & ca. $180 \mathrm{~cm}$ \\
& Richmond and McIntyre 1938-1939 & ca. $150 \mathrm{~cm}$ \\
& Herzig 1946 & $300 \mathrm{~cm}$ \\
& Manning 1975 & $150 \mathrm{~cm}$ \\
& Galsterer 1990 & $125 \mathrm{~cm}$ \\
& Brinkkemper et al. 1995 & $30 \mathrm{~cm}$
\end{tabular}

Bakels 1996

$100 \mathrm{~cm}$

Mauné and Paillet 2003

$40 \mathrm{~cm}$

Demarez et al. 2010

30 to $100 \mathrm{~cm}$

Architecture

Gentry 1976

up to $300 \mathrm{~cm}$

Papi and Martorella 2007

300 to $500 \mathrm{~cm}$

Architecture/

Hermansen 1982

240 to $400 \mathrm{~cm}$

agronomy

Boetto et al. 2016

$160 \mathrm{~cm}(\max .220 \mathrm{~cm})$

Agronomy/history Archives, 1684

ca. $93 \mathrm{~cm}$

Reneaume 1730 [1708]

ca. 6 o to $80 \mathrm{~cm}$

Duhamel 1768

ca. $45 \mathrm{~cm}$

Duhamel 1768

ca. $30 \mathrm{~cm}$

Galiani 1770

60 to $75 \mathrm{~cm}$

Krünitz 1788

$30 \mathrm{~cm}$

Krünitz 1788

ca. $60 \mathrm{~cm}$

Krünitz 1788

90 to $120 \mathrm{~cm}$

Parmentier 1789

30 to $45 \mathrm{~cm}$

Tessier 1793

ca. $45 \mathrm{~cm}$

Tessier 1793

ca. $105 \mathrm{~cm}$

Tessier 1793

ca. $150 \mathrm{~cm}$

Da Gai and Vertucchi 2016

ca. 34 to $68 \mathrm{~cm}$

Mathieu de Dombasle 1862

25 to $40 \mathrm{~cm}$ 
Region or site discussed

\section{Great-Britain \\ Great-Britain \\ Windisch $(\mathrm{CH})$ \\ Great-Britain}

Netherlands

\section{Remarks}

Theoretical value. Storage in bins

Theoretical value. Storage in bins

Theoretical value. Storage in bins

Theoretical value. Storage in bins or bags

Maximum value based on contemporary practices

Mean value for a storage in a cone-shape heap attaining 115 $\mathrm{cm}$ in height at the top

Values probably taken from agronomy treatises

Calculation based on wall thickness; bulk storage. Note that Gentry thought that grain was stored in sacks and not in bulk.

Thamusida (MA)

Calculation based on wall thickness; bulk storage

Ostia, Portus (IT)

Ostia (Iт)

Abtei Weingarten (DE)

France

France

France

France?

Germany

Germany

Germany

France

France

France

France

Venice, Rome (IT)

France
Hermansen relies on parallels from present-day Canada and adapts the value according to the height of the rooms.

The authors do no think that heaps reached $220 \mathrm{~cm}$, which is given as a maximum value.

Maximum height. Hauptstaatsarchiv Stuttgart B 522 Bü 69 . (reference supplied by Lars Blöck)

For fresh (wet) grain; with time grain settles and the height decreases

Mean values observed in public granaries

Very wet grain, 1745 harvest

2,5 feet = maximal height

For wet grain

For dry grain

Maximum height for dry grain

\section{Normal mean height}

1-year-old grain

2-year old grain or older

For bulk storage, depending on dryness. 18 th c. archives

Posthumous, author died in 1843 
TABLE 3.2 Height of grain heaps in the historical, agronomic and archaeological literature (cont.)

\begin{tabular}{|c|c|c|}
\hline Type source & Publication & Height $\mathrm{cm}$ \\
\hline Agronomy/history & Heuzé 1876 & $60 \mathrm{~cm}$ \\
\hline \multirow[t]{8}{*}{ (cont.) } & Desmoulins 1896 & 25 to $30 \mathrm{~cm}$ \\
\hline & Desmoulins 1896 & 50 to $60 \mathrm{~cm}$ \\
\hline & Diffloth 1907 & 15 to $40 \mathrm{~cm}$ \\
\hline & Diffloth 1907 & up to $60 \mathrm{~cm}$ \\
\hline & Ernest and Dumont 1921 & $80 \mathrm{~cm}$ \\
\hline & Sigaut 1981 & $100 \mathrm{~m}$ \\
\hline & Malrain 2000 & $40 \mathrm{~cm}$ \\
\hline & Geraci $2015=$ Geraci and Marin 2016 & 30 and $70 \mathrm{~cm}$ \\
\hline \multirow[t]{9}{*}{ Archaeology } & Knörzer 1970 & 10 to $20 \mathrm{~cm}$ \\
\hline & Gentry 1976 & 10 to $60 \mathrm{~cm}$ \\
\hline & Matterne, Yvinec, and Gemehl 1998 & 20 to $40 \mathrm{~cm}$ \\
\hline & Bouby 2001 & $\begin{array}{l}3 \text { to } 15 \mathrm{~cm} \text { in one spot; } 35 \mathrm{~cm} \\
\text { in another spot }\end{array}$ \\
\hline & Dorow 1826 & $\begin{array}{l}9 \text { to } 24 \mathrm{~cm} \text {, but several feet } \\
\text { in places }\end{array}$ \\
\hline & Matterne 1997 & 20 to $40 \mathrm{~cm}$ \\
\hline & Ruas et al. 2005 & $5 \mathrm{~cm}$ \\
\hline & Ruas 2003 & up to $10 \mathrm{~cm}$ \\
\hline & Borgongino 2006 & $20 \mathrm{~cm}$ \\
\hline
\end{tabular}


Region or site discussed

France

France

France

France

France

France

General

Northern France

General

Neuss (DE)

Ribchester (GB)

Amiens (FR)

Crest "Bourbousson" (FR)

Engers (DE)

Compiègne (FR)

L'Isle-Jourdain "La Gravette" (FR)

Durfort "le Castlar" (FR)

Herculaneum "Villa dei Papiri"

(IT)

\section{Remarks}

Seems to be a maximum height

For grain just harvested

Mean height, when grain has dryied

For fresh grain, depending on dryness. Matterne et al. 1998, 107 cites 4th ed. (1917) with same numbers

For very dry grain in well-built granaries; mean values are lower (gives $33 \mathrm{~cm}$ as an example)

Maximum height for bulk storage with shoveling

Maximum height for bulk storage with shoveling

Discussion with agronomist

Maximum heights for fresh and dry grain. Figures taken from mid-2oth c. Italian agronomy treatises

1st c. CE. Naked wheat

Military (northern granary)

2nd c. CE, urban context. Mainly spelt

3rd c. CE, rural context. Mainly naked wheat, barley in one spot (publication does not specify if hulled or dehusked) 4th c. CE, military post. Mainly naked wheat, with rye and barley

1oth c. CE. Mainly rye and naked wheat

1 th c. CE. Mainly naked wheat, hulled grain stored in chaff 14 th c. CE. Mainly rye and millet; hulled grain at least partially stored in spikelets

1st c. CE. Barley 
TABLE 3.3 A tentative model for calculating grain storage capacities

Points to be considered

Type of cereal stored

Hulled or husked grain

Usable surface area

Thickness of layer

Loss during harvest and storage

\section{Propositions}

See Ouzoulias 2006, 173-177 and other relevant literature, for the various densities

See Ouzoulias 2006, 173-177 and other relevant literature, for the various densities

Mean value of $70 \%$ of total floor area? To be investigated further

20 to $40 \mathrm{~cm}$ (mean value of $30 \mathrm{~cm}$ )

Mean value of $10 \%$ ? To be investigated further

post-harvest losses of 10 to $15 \%$, part of which occurs after rural storage (Postharvest Food Losses in Developing Countries 1978; De Lucia and Assenato 1992). Moreover, grain considered wasted by current standards might still have been consumed or used in other ways in Antiquity (Matterne, Yvinec, and Gemehl 1998, 110; Smith and Kenward 2012, 146-48). We are a long way from the 50 to $80 \%$ wastage rate considered possible by Thomas Gallant $(1991,97-98)$ in his study of ancient Greece, which seems completely implausible to me, ${ }^{8}$ as well as hardly compatible with the low yields he estimates (yields are discussed at more length in Garnsey, Gallant, and Rathbone 1984. On this subject, see also Halstead 2014, 238-50. More generally, on the productivity of ancient peasants, see Kron 2008).

Table 3.3 is an attempt to sum up the different topics discussed in this chapter, and to provide guidelines for calculating the storage capacities of rural granaries. This "model" is put to test in Chapter 6 of this volume, where the reader will find a discussion of historical implications of storage capacity estimates for the Rhine-delta area.

As a general rule, it appears that so far, estimates put forward by scholars for urban and military horrea are much too high. They should certainly not be transposed to rural granaries. Conversely, it must be stressed again that the tentative model presented here is meant for rural sites from the North-Western provinces, and that the focus is on production sites, where fresh grain would enter the granaries each year. This would not necessarily have been the case in

8 I have not been able to consult the literature cited by Gallant but more recent works on postharvest losses in developing countries do not come near a 50-80 \% wastage rate during storage: see e.g. Aulakh and Regmi 2013; 'A Review of Methods for Estimating Grain Post-Harvest Losses' 2015, with previous literature. 
urban and military contexts: the wheat found on the Woerden wreck had been stored for some time previous to its shipping. It should have been dryer than freshly harvested grain and thus presumably storable in higher heaps. Heaps higher than 30 to $40 \mathrm{~cm}$ may also have been more common in granaries used for very short storage periods during transhipments: such may have been the case for the horrea in Portus.

To conclude, the model presented here should be critically assessed before being used or adapted to other types of sites or to another region. This is also true of the historical and ethnographic comparanda we use to compensate the silence of ancient sources. I have been careful to use here mainly French material referring to pre- or early industrial agriculture: although it appears consistent with similar material from Germany and Italy, its general validity for the Western Roman Empire still has to be assessed. 
PART 2

Storage through Time and Space 